\title{
Fuzzy set-based, Integrated Regions' (Countries) Ecological State Evaluation Technique
}

\author{
Tatiana Epifanova ${ }^{1}$, Taras Bogachev $^{2}$, Tamara Alekseychik ${ }^{3}$
}

\begin{abstract}
:
For many countries around the globe, including Russia and its regions, the following situation is common, when economic growth is accompanied with ecological degradation, exhaustion of natural resources and sever deterioration of environment.

Ignorance of ecological factors while preparing the documentation of territorial development doesn't only result in various negative consequences of nature utilization, but also causes deep imbalances between the economic, social and ecological system development.

Authors present the methodic of complex valuation of regional ecological conditions, based on the Fuzzy Set theory, that relies on seven ecological variables (release of pollutants; release of polluted water; detection of air pollutants; clean water usage; volume of used water; number of illnesses per 1000 people; regional funds spent on environmental protection).
\end{abstract}

Keywords: Ecology, ecological conditions, complex valuation.

JEL Classification: $\mathrm{K1}, \mathrm{O13}, \mathrm{CO2}, \mathrm{C} 5$.

\footnotetext{
${ }^{1}$ Corresponding author, Doctor of Economic Sciences, Rostov State University of Economics (RSUE), Rostov-on-Don, Russian Federation, e-mail: profepifanova@gmail.com

${ }^{2}$ PhD of Physico-Mathematical Sciences, Rostov State University of Economics (RSUE),

Rostov-on-Don, Russian Federation, e-mail: bogachev73@yandex.ru

${ }^{3}$ PhD of Economic Sciences, Rostov State University of Economics (RSUE), Rostov-on-Don, Russian Federation,e-mail: alekseychik48@mail.ru
} 


\section{Introduction}

Support for economic growth causes a significant influence on environmental pollution and degradation, climate change, loss of biological variety, human health and other processes. One of the long-run and prioritized tasks in Russia and many developed countries is the creation of favorable conditions for life of citizens and rational utilization of natural resources, without compromising on economic growth. Many regions in Russia are in a situation, where economic growth is accompanied with ecological degradation, exhaustion of natural resources and sever deterioration of environment. Ignorance of ecological factors while preparing the documentation of territorial development doesn't only result in various negative consequences of nature utilization, but also causes deep imbalances between the economic, social and ecological system development.

Therefore, accounting for ecological factor in the regional economic management becomes extremely important. The following study investigates the ecological situation in the South Federal Region (SFR) of Russia. On the territory of SFR, government ecological control is regularly performed. Analysis has determined that the standards of environmental protection are not being followed. Majority of problems are related to not following ecological and sanitary measures when dealing with waste products (39.4\%); late payments of penalties for causing environmental damage (22.5\%); not following ecological requirements when planning, technological and economic grounds of projects, construction work, repair work, enterprise and other object utilization (19.7\%); breaching the rules of atmosphere protection $(13,3 \%)$.

Use of subsurface resources is a mass issue in Volgograd, Dagestan and Kalmykia regions. Mainly, it is used for water supply. 926 individuals have been brought to trial regarding the violation of subsurface resources usage regulations. In 2014 alone, 14824,30 thousand rubles of penalties have been issued, with 11088,90 thousand rubles received $(74,8 \%)$.

The problems of evaluating the ecological conditions and quality of life, as well determining the most favorable countries are considered actual not only in Russia, but in the rest of the world as well. Authors present the methodic of complex valuation of regional ecological conditions, based on the Fuzzy Set theory, that relies on seven ecological variables (release of pollutants; release of polluted water; detection of air pollutants; clean water usage; volume of used water; number of illnesses per 1000 people; regional funds spent on environmental protection).

\section{Literature review}

The problems of stable development and formation of ecology-oriented economy have been investigated in the works of Russian and foreign authors. Significant input, in the formation of the theory of stable development and green economy on 
the regional level, was provided by the scientists N.N. Yashalova (2015), T.V. Epifanova (2013). Legal problems of stable development, preservation of environment and rational nature utilization have been investigated by N. Romanenko (2017). Actual scientific data was extracted from the Rosstat website (2016), in the study conducted by Kravchenko (2016), where the author reviews sanitary and ecologic monitoring in the SFR. While developing the complex valuation of regional ecological conditions based of the Fuzzy Set theory, the analytical methods proposed by T.V. Bogachev (2016) and L.V. Saharova (2017).

In order to classify regions by the level of their economic development, the method proposed N.G. Vovchenko (2013) and T.V. Epifanova (2017) has been used. Shekhovtsov, R.V. (2017), I.A. Zhukova (2017) in their study argued for the correlation between territorial discrepancies and negative impact on the environment, as well as the formation of organizational mechanism and stable development management.

\section{Methods used for conducting research}

Systematization of theoretical arguments, as well development of dependent conditions for stable regional economic development, was carried out using empirical and theoretical methods, including systematic approach, normative, statistical and comparative analysis. Mathematical method of Fuzzy Set theory and economic modeling have been used to conduct the study and develop the method of complex valuation of regional ecological conditions.

\section{Results}

Let's present the proposed methodic of constructing the complex valuation of regional ecological conditions, using SFR as an example (data used was taken from Rosstat for 2005-2015). This method allows to determine the level of ecology in the region, as well as rank the regional subjects on the basis of complex valuation of their ecological conditions. In our case, we consider regional subjects as alternative, which are referred to as follows:

a1 - Adigeya Republic;

a2 - Kalmikiya Republic;

a3 - Krasnodar Region;

a4 - Astrakhan Region;

a5 - Volgograd Region;

a6 - Rostov Region.

amongst which, we must select the best regional subject, based on its ecological condition. 
The offered methodic, has been tested in SFR, excluding the Crimea Region, as the relevant data is not available for the period 2012-2014. Seven selection criteria have been offered:

$\mathrm{X} 1$ - release of pollutants into the atmosphere (000' tonnes);

$\mathrm{X} 2$ - release of polluted water (mln cubic meters);

X3 - number of illnesses per 1000 people;

$\mathrm{X} 4$ - detection of air pollutants from stationary objects (000' tonnes);

X5 - volume of clean water usage (mln cubic meters).

$\mathrm{X} 6$ - volumes of recycled water (mln cubic meters);

$\mathrm{X} 7$ - regional funds spent on environmental protection (mln RUB);

Release of pollutants into the atmosphere - harmful chemicals entering the atmosphere (causing harmful effect on the health of the population and environment), that are emitted by stationary objects. All types of pollutants are being noted, that have been released after being filtered through dust and gas removals (as a result of imperfect filtration). Accounting of these chemicals is performed based on their aggregate conditions (solid, liquid, gas), as well as on components.

The amount of detected chemicals includes all types of pollutants, that have been detected by the dust and gas removals. Stationary pollutant - is a permanent technological apparatus (machine, mechanism), that releases harmful chemical during the process of operation. This includes other objects (terricons, reservoirs and etc.). Clean water usage - use of collected water resources (including sea water) in order to satisfy the household needs. This doesn't include recycled water.

Recycled water usage - volume of clean water saved, due to the operation of recycling water systems, including collection and drainage systems. Recycled water doesn't include water usage in the systems of communal and industrial heating. Polluted sewage water - industrial and communal waste, that has been released into the top water layers, that contain high concentration of pollutants, exceeding the maximum allowed. These don't include drainage systems, that collect water after sprinkling.

Regional funds spent on environmental protection - funds spent by the enterprises, sole-traders and the government, that have a direct environmental security purpose, or are targeting elimination of pollutants and polluted areas. The volume of total environmental protection funds includes capital investment, targeting environmental preservation and rational natural resources utilization, as well as current spending on environmental protection. Due to the fact that the regional subjects contain different territories, the offered ecological indicators will be analyzed as relative indicators result of deciding the ecological indicators for 2016 by the area size of the relevant region (Table 1). 
Table 1. Ecological indicators for 2016 by the area size of the relevant region

\begin{tabular}{|c|c|c|c|c|c|c|c|}
\hline \multirow{2}{*}{$\begin{array}{l}\text { Ecological } \\
\text { indicators }\end{array}$} & \multicolumn{6}{|c|}{ Indictors for 2016 for the unit area of the region } & \multirow{2}{*}{$\begin{array}{l}\text { Indictors } \\
\text { for the } \\
\text { unit area } \\
\text { of the } \\
\text { region }\end{array}$} \\
\hline & $a_{1}$ & $a_{2}$ & $a_{3}$ & $a_{4}$ & $a_{5}$ & $a_{6}$ & \\
\hline $\begin{array}{l}X_{\mathrm{l}}(000, \\
\text { tonnes/1 } \\
\text { kilometer })\end{array}$ & $\begin{array}{c}0,001347 \\
536\end{array}$ & $\begin{array}{c}3,34533 \mathrm{E} \\
-05\end{array}$ & $\begin{array}{c}0,002715 \\
771\end{array}$ & $\begin{array}{c}0,002406 \\
984\end{array}$ & $\begin{array}{c}0,001373 \\
176\end{array}$ & $\begin{array}{c}0,001584 \\
676\end{array}$ & $\begin{array}{l}0,0094615 \\
97\end{array}$ \\
\hline $\begin{array}{ll}X_{2} \text { (mln cubic } \\
\text { metres/ } & 1 \text { sq. } \\
\text { kilometer) } & \end{array}$ & 0,003401 & 0,000147 & 0,011287 & 0,000857 & 0,000904 & 0,002377 & 0,018973 \\
\hline $\begin{array}{l}X_{3} \text { (number of } \\
\text { illnesses per } 1 \\
\text { sq. kilometer) }\end{array}$ & 0,00308 & 0,000562 & 0,000229 & 0,000347 & 0,000234 & 0,000166 & 0,004618 \\
\hline $\begin{array}{l}X_{4}(000, \\
\text { tonnes/1 } \\
\text { kilometer })\end{array}$ & 0,000783 & $4,28 \mathrm{E}-06$ & 0,016427 & 0,000133 & 0,001772 & 0,000166 & 0,019285 \\
\hline $\begin{array}{ll}X_{\mathrm{s}}(\mathrm{mln} & \\
\text { metres/ } & \text { cubic } \\
\text { kilometer }) & \end{array}$ & 0,022331 & 0,005379 & 0,041068 & 0,01485 & 0,005138 & 0,021245 & 0,11001 \\
\hline $\begin{array}{l}X_{6} \text { (mln cubic } \\
\text { metres/ 1sq. } \\
\text { kilometer) }\end{array}$ & 0,002823 & $6,69 \mathrm{E}-07$ & 0,021859 & 0,010566 & 0,012314 & 0,047738 & 0,095302 \\
\hline $\begin{array}{l}X_{7} \text { (mln RUB/ } \\
1 \text { sq. kilometer) }\end{array}$ & 0,041068 & 0,002114 & 0,143962 & 0,086549 & 0,068269 & 0,057415 & 0,399378 \\
\hline
\end{tabular}

Based on the criteria stated above for the period 2005-2015, authors have carried out analysis of the dynamics of relevant indicators and have constructed relevant trend models. As a result of econometrical analysis of the quality of constructed models, it 
was identified that these models are statistically important, don't contain autocorrelation, however heteroskedasticity is present in some equations. However, when considering high determination coefficient, these equations can be used to forecast for the year 2016. Forecast figures for 2016 of the investigated ecological factors are used in further analysis of complex valuation of regional ecological conditions in 2016, using the Fuzzy Set theory.

While determining the valuation of ecological conditions of regional subjects, the proposed indicators have a varying significance. Therefore, the authors introduce weighted coefficients of the indicators for each subject of SFR as a share, relevant to the particular region (Table 2).

Table 2. Weighted coefficients of regional ecological indicators

\begin{tabular}{|c|c|c|c|c|c|c|c|}
\hline \multirow{2}{*}{$\begin{array}{l}\text { Ecological } \\
\text { indicators }\end{array}$} & \multicolumn{6}{|c|}{ Weighted coefficients of regional indicators } & \multirow{2}{*}{$\begin{array}{l}\text { The } \\
\text { significance of } \\
\text { the indicator } \\
\text { for the region, } \\
\text { per unit of } \\
\text { regional area }\end{array}$} \\
\hline & $a_{1}$ & $a_{2}$ & $a_{3}$ & $a_{4}$ & $a_{5}$ & $a_{6}$ & \\
\hline$X_{1}$ & $\begin{array}{l}0,1424 \\
18\end{array}$ & $\begin{array}{l}0,0035 \\
35\end{array}$ & $\begin{array}{l}0,2870 \\
31\end{array}$ & $\begin{array}{l}0,2543 \\
95\end{array}$ & $\begin{array}{l}0,1451 \\
32\end{array}$ & $\begin{array}{l}0,16748 \\
5\end{array}$ & 0,009461597 \\
\hline$X_{2}$ & $\begin{array}{l}0,1792 \\
55\end{array}$ & $\begin{array}{l}0,0077 \\
48\end{array}$ & \begin{tabular}{|l|}
0,5948 \\
99
\end{tabular} & $\begin{array}{l}0,0451 \\
69\end{array}$ & $\begin{array}{l}0,0476 \\
47\end{array}$ & 0,12527 & 0,018973 \\
\hline$X_{3}$ & $\begin{array}{l}0,7209 \\
74\end{array}$ & $\begin{array}{l}0,1315 \\
54\end{array}$ & $\begin{array}{l}0,0509 \\
18\end{array}$ & $\begin{array}{l}0,0509 \\
18\end{array}$ & $\begin{array}{l}0,0519 \\
88\end{array}$ & $\begin{array}{l}0,03688 \\
1\end{array}$ & 0,004618 \\
\hline$X_{4}$ & $\begin{array}{l}0,0406 \\
02\end{array}$ & $\begin{array}{l}0,0002 \\
22\end{array}$ & $\begin{array}{l}0,8518 \\
02\end{array}$ & $\begin{array}{l}0,0068 \\
96\end{array}$ & $\begin{array}{l}0,0920 \\
52\end{array}$ & $\begin{array}{l}0,00860 \\
8\end{array}$ & 0,019285 \\
\hline$X_{5}$ & $\begin{array}{l}0,2029 \\
91\end{array}$ & $\begin{array}{l}0,0488 \\
95\end{array}$ & $\begin{array}{l}0,3733 \\
12\end{array}$ & $\begin{array}{l}0,1349 \\
88\end{array}$ & $\begin{array}{l}0,0467 \\
05\end{array}$ & $\begin{array}{l}0,19311 \\
9\end{array}$ & 0,11001 \\
\hline$X_{6}$ & $\begin{array}{l}0,0296 \\
22\end{array}$ & $\begin{array}{l}0,0000 \\
07\end{array}$ & $\begin{array}{l}0,2293 \\
65\end{array}$ & $\begin{array}{l}0,1108 \\
69\end{array}$ & $\begin{array}{l}0,1292 \\
1\end{array}$ & $\begin{array}{l}0,50091 \\
3\end{array}$ & 0,095302 \\
\hline$X_{7}$ & $\begin{array}{l}0,1028 \\
3\end{array}$ & $\begin{array}{l}0,0052 \\
93\end{array}$ & $\begin{array}{l}0,3604 \\
65\end{array}$ & $\begin{array}{l}0,2167 \\
09\end{array}$ & $\begin{array}{l}0,1709 \\
38\end{array}$ & $\begin{array}{l}0,14376 \\
1\end{array}$ & 0,399378 \\
\hline
\end{tabular}

Processing the following information applying the Fuzzy Set Theory, authors introduce $X_{1}, X_{2}, X_{3}, X_{7}$ as the expected and desired, compared to the largest values of corresponding indicators per unit of area. Let's determine the share of 
indicator values for 2016, per unit of area, compared to the largest values in the given period (Table 3 ).

Table 3. Expected valuation of ecological indicators

\begin{tabular}{|l|l|l|l|l|l|l|l|l|l|l|l|l|}
\hline \multirow{2}{*}{$\begin{array}{l}\text { Environmen } \\
\text { tal } \\
\text { indicators }\end{array}$} & \multicolumn{9}{|l|}{$\begin{array}{l}\text { Expected assessments of indicators } \\
\text { of subjects of the region }\end{array}$} \\
\cline { 2 - 14 } & $\begin{array}{l}a_{1} \\
\text { subjects }\end{array}$ & $a_{2}$ & $a_{3}$ & $a_{4}$ & $a_{5}$ & $a_{6}$ & $a_{1}$ & $a_{2}$ & $a_{3}$ & $a_{4}$ & $a_{5}$ & $a_{6}$ \\
\hline$X_{1}$ & $\begin{array}{l}0,95 \\
74\end{array}$ & $\begin{array}{l}0,09 \\
57\end{array}$ & $\begin{array}{l}0,12 \\
86\end{array}$ & $\begin{array}{l}0,04 \\
2\end{array}$ & $\begin{array}{l}0,03 \\
43\end{array}$ & $\begin{array}{l}0,01 \\
87\end{array}$ & $\begin{array}{l}0,001 \\
412\end{array}$ & $\begin{array}{l}0,000 \\
094\end{array}$ & $\begin{array}{l}0,002 \\
861\end{array}$ & $\begin{array}{l}0,002 \\
733\end{array}$ & $\begin{array}{l}0,001 \\
781\end{array}$ & $\begin{array}{l}0,001 \\
981\end{array}$ \\
\hline$X_{2}$ & $\begin{array}{l}0,91 \\
89\end{array}$ & $\begin{array}{l}0,33 \\
41\end{array}$ & $\begin{array}{l}0,92 \\
62\end{array}$ & $\begin{array}{l}0,59 \\
1\end{array}$ & $\begin{array}{l}0,54 \\
79\end{array}$ & $\begin{array}{l}0,89 \\
89\end{array}$ & $\begin{array}{l}0,003 \\
722\end{array}$ & $\begin{array}{l}0,000 \\
44\end{array}$ & $\begin{array}{l}0,012 \\
19\end{array}$ & $\begin{array}{l}0,001 \\
45\end{array}$ & $\begin{array}{l}0,001 \\
649\end{array}$ & $\begin{array}{l}0.002 \\
67\end{array}$ \\
\hline$X_{3}$ & $\begin{array}{l}0,85 \\
32\end{array}$ & 1 & $\begin{array}{l}0,76 \\
67\end{array}$ & $\begin{array}{l}0,41 \\
64\end{array}$ & $\begin{array}{l}0,86 \\
67\end{array}$ & $\begin{array}{l}0,79 \\
05\end{array}$ & $\begin{array}{l}0,003 \\
606\end{array}$ & $\begin{array}{l}0,000 \\
54\end{array}$ & $\begin{array}{l}0,000 \\
3\end{array}$ & $\begin{array}{l}0,000 \\
55\end{array}$ & $\begin{array}{l}0,000 \\
27\end{array}$ & $\begin{array}{l}0,000 \\
21\end{array}$ \\
\hline$X_{7}$ & $\begin{array}{l}0,01 \\
17\end{array}$ & $\begin{array}{l}0,20 \\
36\end{array}$ & $\begin{array}{l}0,01 \\
31\end{array}$ & $\begin{array}{l}0,04 \\
55\end{array}$ & $\begin{array}{l}0,01 \\
95\end{array}$ & $\begin{array}{l}0,01 \\
67\end{array}$ & $\begin{array}{l}0,060 \\
2\end{array}$ & $\begin{array}{l}0,002 \\
8\end{array}$ & $\begin{array}{l}0,149 \\
1\end{array}$ & 0,091 & $\begin{array}{l}0,156 \\
1\end{array}$ & $\begin{array}{l}0,082 \\
2\end{array}$ \\
\hline
\end{tabular}

Let's introduce $X_{4}, X_{5}, X_{6}$, as expected and desired, when compared to the smallest values of corresponding indicators per unit of are of the subject in the given period. Let's determine the share of indicator values for 2016, per unit of area, compared to the smallest values in the given period (Table 4).

Table 4. Expected valuation of ecological indicators

\begin{tabular}{|c|c|c|c|c|c|c|c|c|c|c|c|c|}
\hline \multirow{2}{*}{$\begin{array}{c}\text { Environmen } \\
\text { tal } \\
\text { indicators }\end{array}$} & \multicolumn{6}{|c|}{$\begin{array}{l}\text { Expected assessments of indicators } \\
\text { of subjects of the region }\end{array}$} & \multicolumn{6}{|c|}{$\begin{array}{l}\text { The maximum value } \\
\text { subjects }\end{array}$} \\
\hline & $a_{1}$ & $a_{2}$ & $a_{3}$ & $a_{4}$ & $a_{5}$ & $a_{6}$ & $a_{1}$ & $a_{2}$ & $a_{3}$ & $a_{4}$ & $a_{5}$ & $a_{6}$ \\
\hline$X_{4}$ & $\begin{array}{l}0,02 \\
7\end{array}$ & 3,2 & $\begin{array}{l}1,90 \\
7\end{array}$ & $\begin{array}{l}0,00 \\
5\end{array}$ & $\begin{array}{l}0,06 \\
7\end{array}$ & $\begin{array}{l}0,000 \\
46\end{array}$ & $\begin{array}{l}0,000 \\
5\end{array}$ & $\begin{array}{l}0,000 \\
0013\end{array}$ & $\begin{array}{l}0,008 \\
6\end{array}$ & $\begin{array}{l}0,000 \\
12\end{array}$ & $\begin{array}{l}0,001 \\
4\end{array}$ & $\begin{array}{l}0,008 \\
6\end{array}$ \\
\hline$X_{5}$ & $\begin{array}{l}0,02 \\
5\end{array}$ & $\begin{array}{l}1,38 \\
5\end{array}$ & 1,03 & $\begin{array}{l}0,99 \\
7\end{array}$ & $\begin{array}{l}0,98 \\
1\end{array}$ & 0,024 & $\begin{array}{l}0,015 \\
3\end{array}$ & $\begin{array}{l}0,003 \\
9\end{array}$ & $\begin{array}{l}0,039 \\
8\end{array}$ & $\begin{array}{l}0,014 \\
9\end{array}$ & $\begin{array}{l}0,005 \\
2\end{array}$ & 0,021 \\
\hline$X_{6}$ & 0,8 & 0,5 & 1,13 & 2,23 & $\begin{array}{l}0,07 \\
68\end{array}$ & 1,39 & $\begin{array}{l}0,003 \\
5\end{array}$ & $\begin{array}{l}0,000 \\
0013\end{array}$ & $\begin{array}{l}0,019 \\
5\end{array}$ & $\begin{array}{l}0,004 \\
7\end{array}$ & $\begin{array}{l}0,012 \\
2\end{array}$ & $\begin{array}{l}0,034 \\
3\end{array}$ \\
\hline
\end{tabular}

While using the corresponding weighted coefficients of ecological indicators and their expected valuation, lets determine the Fuzzy Sets for these indicators for each regional subject: 


$$
\begin{aligned}
& \mu_{X 1}=0,1362 / 0,0013+0,0003 / 3,34533 \mathrm{E}-05+0,0369 / 0,0027+ \\
& 0,0107 / 0,0024+0,0050 / 0,00137+0,0031 / 0,0016 \\
& \mu_{X 2}=0,1647 / 0,0034+0,00269 / 0,0001+0,5509 / 0,0112+0,0265 / 0,0008+0,0261 / 0,0009+ \\
& +0,1126 / 0,0023 \\
& \mu_{X 3}=0,6151 / 0,0031+0,1355 / 0,0005+0,0390 / 0,0002+0,02120 / 0,0003+0,04506 / 0,0002+ \\
& 0,0292 / 0,0002 \\
& \mu_{X 4}=0,0038 / 0,0007+0,01131 / 4,28 \mathrm{E}-06+0,54737 / 0,0164+ \\
& 0,001272 / 0,0001+0,00972 / 0,0017+0,00077 / 0,0001 \\
& \mu_{X 5}=0,00448 / 0,0223+0,0107 / 0,0054+0,61276 / 0,0411+0,04503 / 0,0149+0,04674 / 0,0051 \\
& +0,0030 / 0,0212 \\
& \mu_{X 6}=0,57678 / 0,0028+0,06577 / 6,69 \mathrm{E}-07+0,05754 / 0,0218+ \\
& 0,1135 / 0,0106+0,00399 / 0,0123+0,05126 / 0,0477 \\
& \mu_{X 7}=0,0012 / 0,0411+0,0011 / 0,0021+0,0047 / 0,144+0,0098 / 0,0865+0,0033 / 0,0682+ \\
& 0,0024 / 0,0574
\end{aligned}
$$

In order to determine the best regional subjects, in terms of ecological conditions and development, lets apply the convolution method in the Fuzzy Set theory. The set of optimal alternatives for B, accounting for different significance of ecological indicators, is determined by the intersection of Fuzzy Sets, which corresponds to the minimal value of each regional subject:

$B=\{\min \{0,1362 ; 0,1647 ; 0,6151 ; 0,0038 ; 0,0045 ; 0,05768 ; 0,0012\}$, $\{\min \{0,0003 ; 0,0027 ; 0,1355 ; 0,0113 ; 0,0107 ;, 0658 ; 0,0011\}$, $\{\min \{0,0369 ; 0,5509 ; 0,0390 ; 0,5474 ; 0,6127 ; 0,0575 ; 0,0047\}$, $\{\min \{0,0107 ; 0,0267 ; 0,0212 ; 0,0013 ; 0,0450 ; 0,1135 ; 0,0098\}$, $\{\min \{0,0050 ; 0,0261 ; 0,0451 ; 0,0097 ; 0,0467 ; 0,0040 ; 0,0033\}$, $\{\min \{0,0031 ; 0,1126 ; 0,0292 ; 0,0008 ; 0,0031 ; 0,0513 ; 0,0024\}$.

Therefore, set B, is of the following type:

$\mathrm{B}=\{0,0012 ; 0,0003 ; 0,0047 ; 0,0013 ; 0,0033 ; 0,00008\}$.

Obtaining:

$\operatorname{Max}\{0,0012 ; 0,0003 ; 0,0047 ; 0,0013 ; 0,0033 ; 0,00008\}=0,0047$. 
Set of optimal alternatives for B can be considered as the complex valuation of the region, or as the integral analysis of ecological conditions in the SFR. This set allows to range the regional subjects, according to the level of ecological development. The best ecological conditions are in the Rostov Region, followed by Kalmikiya Republic, Republic of Adigeya, Astrakhan Region, Volgograd Region and finally Krasnodar Region.

\section{Conclusion}

As a result of the study, the following methodic of computing the complex valuation of regional ecological conditions can be proposed for forecasting the values of ecological indicators for the nearest future (Table 5).

Table 5. Regional ecological conditions

\begin{tabular}{|c|c|}
\hline Research Stages & Actions \\
\hline Stage 1 & Select the subjects of the region investigated. \\
\hline Stage 2 & $\begin{array}{l}\text { Carry out the selection of the main indicators, which will be used in } \\
\text { the complex valuation of the regional ecological development. } \\
\text { Regional specialists are required at this stage. }\end{array}$ \\
\hline Stage 3 & $\begin{array}{l}\text { Collect the data on the main indicators, explaining various aspects of } \\
\text { the regional ecological conditions. }\end{array}$ \\
\hline Stage 4 & $\begin{array}{l}\text { Computation with the use of econometrical methods, via trend } \\
\text { modeling for the main indicators. }\end{array}$ \\
\hline Stage 5 & $\begin{array}{l}\text { Valuation of quality of trend equations for the main indicators of } \\
\text { regional ecological conditions. }\end{array}$ \\
\hline Stage 6 & Calculating the forecast values for ecological indicators. \\
\hline Stage 7 & Determining the weighted coefficients. \\
\hline Stage 8 & $\begin{array}{l}\text { Determining the shares of calculated values compared to the } \\
\text { largest/smallest (desired) values of corresponding indicators. }\end{array}$ \\
\hline Stage 9 & Determining the Fuzzy Sets and ecological indicators. \\
\hline Stage 10 & $\begin{array}{l}\text { Computation of the complex valuation of regional ecological } \\
\text { conditions for the nearest future period by the convolution method. }\end{array}$ \\
\hline Stage 11 & $\begin{array}{l}\text { Interpreting and analyzing the results, as well as recommendation of } \\
\text { the necessary measures to improve ecological conditions. }\end{array}$ \\
\hline
\end{tabular}

The strategy of SFR development is aimed at increasing the level and quality of life, primarily via effective use of natural resources, transport, geographical and sociodemographic potential. 
Application of this methodic, tested on SFR (Adigeya Republic, Kalmikiya Republic, Astrakhan Region, Volgograd Region, Rostov Region and Krasnodar Region) allows to rank the regions accruing to the level of ecological development, obtain complex data on the environmental conditions; formulate necessary government measures necessary to rehabilitate the region in case of ecological threat; evaluate the effectiveness of government actions to improve ecology in the regions around Russia.

\section{References:}

Bogachev, V.T., Alekseychik, V.T., Styukov, B.M., Gnedash, S.E. 2016. Analysis of optimal transport vehicles for transporting in the Rostov Region. International Applied Science Conference «Russia and the EU: Development Paths and Potential». Rostov-On-Don, available at: http://rsue.ru/rstv/sbornik.pdf

Epifanova, T.V., Skvortsova, T.A., Parshina, E.A. 2017. Influence of clustering on innovational development of business structures in region's economy. International Journal of Trade and Global Markets.

Epifanova, V.T., Verved, V.V. 2017. Green Nation as the basis of stable regional development. Gaps in the Russian Legislation. Law Journal, №3, 170-171.

Federal Statistics website: http://www.gks.ru/wps/wcm/connect/rosstat_main/rosstat/ru/statistics/environment/

Kravchenko V.V., Omelchenko E.V. 2016. Sanitary and Ecological Monitoring in the South Federal Region. Young Scientist. №18.1, 14-16.

Romanenko, G.N., Epifanova, V.T. 2017. Convergence of Nutrition Standards in the beekeeping industry: legal aspects. Timber Journal, 7th Edition №1 (25), 97-98.

Sakharova, V.L., Alekseychik, V.T., Styukov, B.M., Bogachev, V.T. 2017. Method of valuation of agricultural production using the Fuzzy Set theory. International science journal, №07, (61), part 3, 123-129.

Shekhovtsov, V.R., Yaroshenko, G.S., Khaibullin, R.L. 2017. Instruments of Investment Attraction in Order to Fulfill the Structural Priorities of Sustainable Regional Development (Study Based on the Rostov Region) Special Issue dedicated to the International Conference "Russia and EU: Development and Horizons", European Research Studies Journal, 20(1), 337-349.

Vovchenko N.G., Epifanova T.V. 2013. Valuation of institutional environment in Russia. Theory and Practice of Social Development. № 8, 95.

Yashalova, N.N. 2015. Stimulation of stable regional ecological development. PhD dissertation, Moscow, 149-166.

Zhukova, A.I., Shekhovtsov, V.R., Ponomareva, A.M., Tyaglov, G.S. 2017. The Mechanism to Eliminate the Accumulated Damage to the System of Socio-Economic Development of the Region. European Research Studies Journal, 20(3B), 67-75. 